\title{
CHANGES OF GRASSLAND VEGETATION IN SURROUNDINGS OF NEW RAILWAY FLYOVER (EASTERN BOHEMIA, CZECH REPUBLIC). PART I: PLANT COMMUNITIES AND PERMANENT HABITAT PLOTS
}

\author{
LENKa JANDOVÁ, PETR SKLENÁŘ, PAVEL KovÁŘ
}

Charles University in Prague, Faculty of Science, Benátská 2, 12801 Prague 2, Czech

Republic, e-mail: kovar@natur.cuni.cz.

Received: $11^{\text {th }}$ November 2008, Accepted: $10^{\text {th }}$ April 2009

\begin{abstract}
Paper shows (1) the results based on vegetation monitoring during the time period 19752005 in the grassland segment of undulated landscape along railway corridor close to village Dlouhá Třebová (Ústí nad Orlicí district, Eastern Bohemia, Czech Republic). Survey was focused on the meadow communities, identification of phycenological changes by comparison of historical phytosociological records (1975) with the present ones (2005). (2) Actual relevés taken within transect design showed that there is direct dependence between the meadow species composition and soil moisture gradient. Along the soil moisture gradient different formations can be found: Carex acuta communities occupying the wet sites close to river bank with high groundwater table, followed by wet Calthion meadows with Cirsium rivulare in mosaic with Holcus lanatus formation on drier microsites. Arrhenatherum elatius stands grow in mesic conditions in contact with Calthion wet meadows. Dry sites on high slope are dominated by Festuca rubra. There are also some plant species of semi-thermophilous flora and species that prefer more acid soil reaction as a part of grassland complex. Meadow biotopes which were not affected by site alteration during bridge building, and communities with Carex acuta seem to be relatively stable in time. There are two populations of protected rare plant species in the locality: first an orchid Dactylorhiza majalis and the second Gentianopsis ciliata. (3) The railway reconstruction resulted mainly into degradation processes of grassland sites which is documented by the sown plant mixture or ruderal plant assemblages.
\end{abstract}

Key words: field recording, phytosociological relevés, railway corridor, flyover construction, habitat monitoring, permanent plots, biodiversity

\section{INTRODUCTION}

Species-rich grasslands covering extensive patches of land have almost disappeared from the Czech Republic. Only rarely we can find examples of a wider scope of interconnected or mosaic-like communities that have been preserved under the traditional system of farming (Kováŕ, 2003). Until recently one such locality could be found in the floodplain of the Třebovka river, close to the railway station Dlouhá Třebová in Eastern Bohemia. This locality was connected to a series of grassland communities that could be found on a rising slope of an adjoining hill all the way to the hilltop. The interruption of the ecological catena 
by an old railway bank, which had in fact followed the terrain, had not represented any significant disturbance of the characteristic gradient of species diversity. In 2003 a concrete flyover spanned the floodplain. The construction was embedded in the ground of the flat alluvial plain by a set of piers. At the same time extensive landscaping was carried out around the building site, which affected various parts of the valuable grassland complex.

This paper focuses on the description of the current flora and vegetation of the grassland catena, records the changes of its communities in comparison with the historical state and suggests possible solutions that would lead to a restoration of extinct grassland communities.

We can phrase the above mentioned aims of this paper as questions:

1) Which vegetation types of grassland communities occur in the locality along the ecological catena and/or altitudinal gradient? What is their dependence on basic ecological parameterts of habitats?

2) Which biotopes were present in the locality in the past (according to available data) and which are present now?

3) What changes occurred within the thirty-year span on the surveyed sites (on the permanent plots) and what does the detected exchange of plant species indicate?

\section{STUDY SITE}

The chosen locality (grassland complex) lies in the cadastral area of the village of Dlouhá Třebová. It is very close to Česká Třebová (Eastern Bohemia, district Ústí nad Orlicí, Czech Republic).

From the regional geomorphological point of view the area belongs to the province of Bohemian Highlands (Česká Vysočina). The western part of the district belongs to the system of Bohemian Table (Česká tabule), the subsystem East Bohemian Table, which consists of upper cretaceous sediments. Dlouhá Třebová lies in Ústí nad Orlicí furrow (Faltysová et Bárta, 2002). The base is formed by cretaceous freshwater and seawater sediments. Unconsolidated sediments (clays and gravels) prove the presence of the sea in the Neogene period (Neuhäuslová et al., 2001).

According to Quitt (1971) the surveyed area can be assessed as mildly warm (MW) climatic region. In Quitt's zoning map (Quitt, 1971) the lower part of the meadow catena belongs to unit MW 2, whereas the upper rising part belongs to unit MW 7. The border between them runs more or less parallel to the railway track.

The Třebovka river, which runs through Dlouhá Třebová, is a locally significant watercourse. It is a right-side tributary of the Tichá Orlice river and has an average rate of flow of ca $0.6 \mathrm{~m}^{3} / \mathrm{s}$. The main European watershed runs through the territory of the district; Třebovka drains the area into the river Labe (the North Sea). Třebovka's floodplain lies in the so-called Ústí nad Orlicí syncline.

From the phytogeographical point of view the surveyed area belongs to Mesophyticum, namely to the phytogeographical area of the Bohemian-Moravian Mesophyticum, Bohemian-Moravian Highlands, Českotřebovský úval-Dale. As for floroelements, mesophytes prevail over termophytes of supracolline vegetation zone. The area went primarily through a forest development of vegetation and flora with an adequate soil genesis. It has been changed substantially by human activity. A partial deforestation occurred gradually during the Middle Ages (Hejný et Slavík, 1988). According to 
Neuhäuslová et al. (2001) the potential natural vegetation in this area is assoc. Melampyro nemorosi-Carpinetum.

The surveyed section of landscape in the territory of the village of Dlouhá Třebová has an area of $1 \mathrm{~km}^{2}$ and primarily contains the local grassland catena, i.e. a chain of ecosystems spread between the flat and the rising part of the area. The altitude of the alluvial plain is ca $380 \mathrm{~m}$. Grassy slopes lead up westward past the hill Hůrka $(427 \mathrm{~m})$ to the spot height Zacharovec $(438 \mathrm{~m})$ (Kovár, 2003). The catena is interrupted by a road and a former railway embankment, which divides the catena into two parts. The lower alluvial part (ca $0.1 \mathrm{~km}^{2}$ ) borders on three sides with small ditches that are connected with the Třebovka river. On the opposite side it borders with the former railway embankment. This area is intersected with a road. In the section between the road and the embankment we can find the new flyover, which is supported by piers. It was here that the most extensive landscaping occurred. The hillside of the meadow behind the embankment (ca $0.2 \mathrm{~km}^{2}$ ) goes up steeply. In the steepest part the slope reaches $20^{\circ}$ and the slope widens. Besides these two bigger grassland complexes there are other newly arisen biotopes or stands either in the place of the former meadows or outside them. The length of the whole catena is approximately $950 \mathrm{~m}$.

Except for the fragments of high sedges the stands are regularly mown and harvested with heavy machinery. This is done twice a year, first at the end of May, then between July and August. Several 50-cm-deep drains were dug up in the floodplain (altitude is about 350 $\mathrm{m})$. The stands on the slope are also mown twice a year with a slight delay compared to the alluvial ones. Over the last few years this area has not been mown completely, which is shown by the presence of standing dead and self-sown trees on the steepest slopes. All meadows are unfertilised and in the past livestock were occasionally pastured here (cattle and horses).

The questions raised in this study were provoked by the interference in stabilised habitats caused by the construction works during the modernisation of the railway line which intersects this grassland complex. The chosen railway sector Ústí nad Orlicí - Česká Třebová is a part of transit corridor, which constitutes a section of the international railway connection Berlin - Prague - Vienna The construction started in May 2002 and finished in March 2004. This part of the railway was straightened and diverted from the original railway bank. Original transition curves were removed in order to increase rail speed. Curves were replaced by an 1150-metre-long shifting of tracks with a newly built 417metre-long bridge construction from reinforced concrete placed directly behind the station Dlouhá Třebová.

\section{MATERIAL AND METHODS}

\section{Flora and vegetation records}

Plant species: The assessment of grasslands was carried out along the catena floodplain hillside. The recorded species included rare, protected and threatened species and also species with high nature conservation importance (in the case of Dactylorhiza majalis the number of specimens was recorded as well). The other biotopes and the body of the embankment were also mapped and evaluated using an inventory of the present species and their spatial pattern.

Phytocoenological records: Relevés were done in optimal seasonal period before regular mowing (mostly in the end of May or at the beginning of June, event. in July in case of uncut stands). Standardized size of one relevé was 5 x $5 \mathrm{~m}$ in permanent plots, present species were 
recorded using Braun-Blanquet's seven-grade semi-quantitative scale of abundance and dominance (Braun-Blanquet, 1928) with a subdivision of degree 2 in case of relevés along 4 transects (Prach, 1994, 1996). The abundance of the herb layer $\left(E_{1}\right)$, the layer of cryptograms, i.e. bryophytes $\left(\mathrm{E}_{0}\right)$ and in the uncut rising part also the shrub layer $\left(\mathrm{E}_{2}\right)$ was recorded. The shrub layer includes woody species from 1 to 3 metres in height (Moravec, 1994, Prach, 1996). Saplings of woody plants that did not reach 1 metre in height were included in the herb layer. Nomenclature of vascular plants was unified according to Kubát et al. (2002). The phytocenological classification sensu Braun-Blanquet was concentrated only on grasslands. By choosing systematically positioned plots we followed the formalised classification method (Chytrý, 2000).

Transect plots: We placed 4 line transects along the rising gradient of the terrain (floodplain - hillside) with 10 squares in each transect (rows 1 to 10) - see Fig. 1. Because the hillside was much wider than alluvial part of the meadow, it was necessary to add two more squares in rows 7 and 8 to obtain vegetation data for uncut stands. The distances between individual rows within transects were from 40 to $70 \mathrm{~m}$, in the upper part they reached up to $100 \mathrm{~m}$. Vegetation relevés were taken during the season 2005.

In the floodplain of the grassland complex, we placed 16 relevés in 4 line transects (rows 1 to 4). Three fixed plots (T/VI and T/VII in cut stand and T/IV in uncut stand) occur in this part of the locality as well. Five transect relevés (row 5), four fixed plots in cut stand (T/I, T/II, T/III and T/VIII) and one fixed plot in uncut stand (T/IV) are located in a smaller stretch between the road and the railway embankment - a place of extensive construction works and piers anchoring. Transect relevés in the upper rising part of the meadow cover both cut and uncut area almost up to the forest line in the highest point of the ecological catena. 8 relevés were situated in an uncut part (I/6, I/7, II/7, III/7, I/8, II/8 and III/8), 15 relevés were placed in a cut part (II/6, III/6, IV/6, IV/7, V/7, IV/8, V/8, row 9 and 10). One fixed plot (T/IX) was placed in uncut stand with an advanced phase of successional overgrowing by shrubs. Spatial positioning of relevés in the above mentioned grassland complex can be seen in Fig. 1.

Squares in transects were fixed by nails with plastic washers. The aim was to detect nails the following season by a metal detector. Squares in the uncut part of the stand were marked off by wooden pegs. The position of squares was measured by a measuring tape from suitable points of reference in the surroundings and the location was determined by GPS. Standard data were added to the records of phytosociological relevés: date, geographical location, relief, the area of the relevé and an approximate area of the site with a given type of stand (Kovár, 2001). After entering coordinates into the digital map database in ArcGIS program, application ArcMap 9.2, other information on the slope, altitude and hillside orientation were obtained.

Permanent plots: The changes on the long-term time axis were documented by relevés from 10 permanent plots. All permanent plots were established, marked and recorded in 1975 during a more extensive collection of phytosociological data for Eastern Bohemia (Kovár, handwritten records). These permanent plots cover both meadow formations and other habitats of waterlogged sites of the floodplain. They were chosen subjectively without any specific formalised design - the location criterion was typical structure of plant communities. The author continued in vegetation records on the same plots also in 2001 and 2004. These records were completed by records from 2005 and 2006 (Jandová, 2007). The time sequence of the records is not complete for all the relevés as some localities do not exist any more. Immediately after finishing the construction of the railway flyover in 2004 a new plot was added to the fixed plots. It was placed on the original, now non- 
utilized railway embankment to monitor changes in newly established habitat spatialy connected to grassland communities.

Fig. 1: Spatial positioning of vegetation relevés (Transects are represented by rows from 1 to 10 marked in white. Fixed plots from T/I to T/X are marked in yellow).

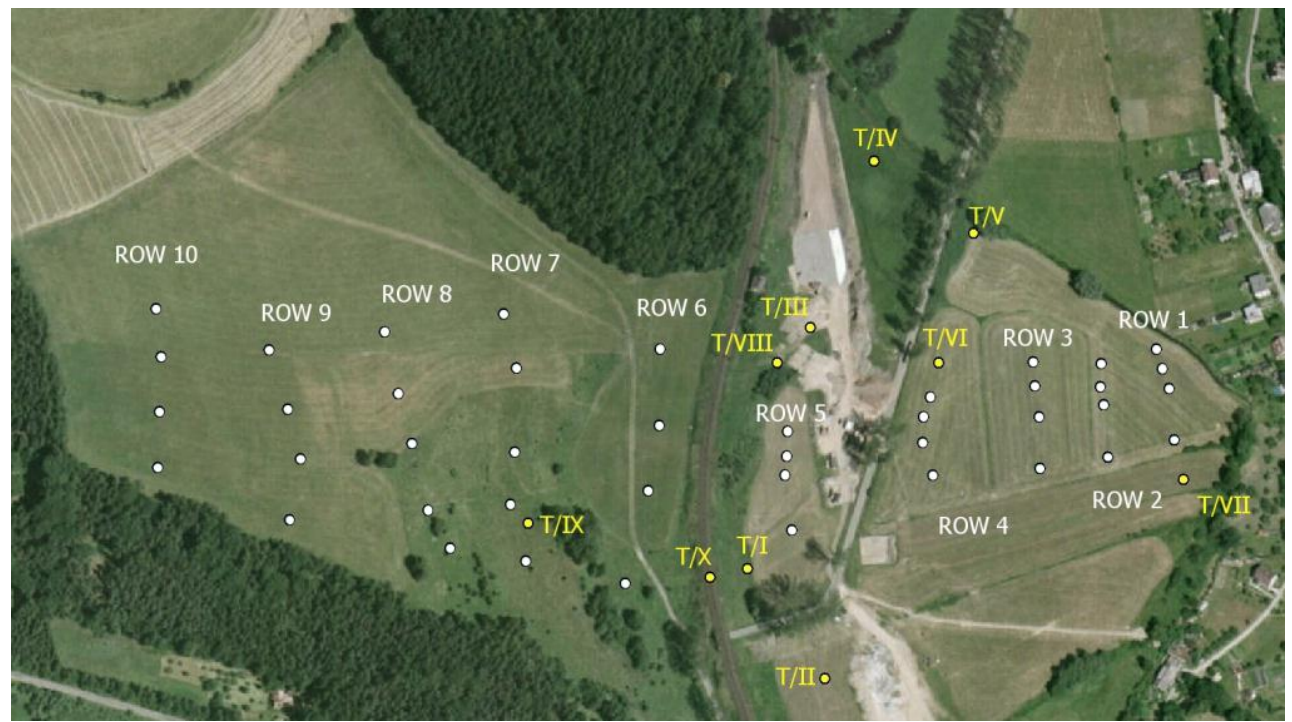

Notes: row 1 contains relevés $\mathrm{I} / 1$ to IV $/ 1$, row 2 relevés $\mathrm{I} / 2$ to IV $/ 2$, row 3 relevés $\mathrm{I} / 3$ to IV $/ 3$, row 4 relevés $\mathrm{I} / 4$ to $\mathrm{IV} / 4$, row 5 relevés $\mathrm{I} / 5$ to $\mathrm{IV} / 5$, row 6 relevés $\mathrm{I} / 6$ to $\mathrm{IV} / 6$, row 7 relevés $\mathrm{I} / 7$ to $\mathrm{V} / 7$, row 8 relevés $\mathrm{I} / 8$ to $\mathrm{V} / 8$, row 9 relevés $\mathrm{I} / 9$ to $\mathrm{V} / 9$ and row 10 relevés $\mathrm{I} / 10$ to $\mathrm{V} / 10$. (according to Jandová, 2007; source of map: www.cenia.cz/geoportal)

Photo 1: Grassland complex crossed by the old railway embankment and new flyover construction (view from the top of the meadow catena, June 2006; photo L. Jandová)

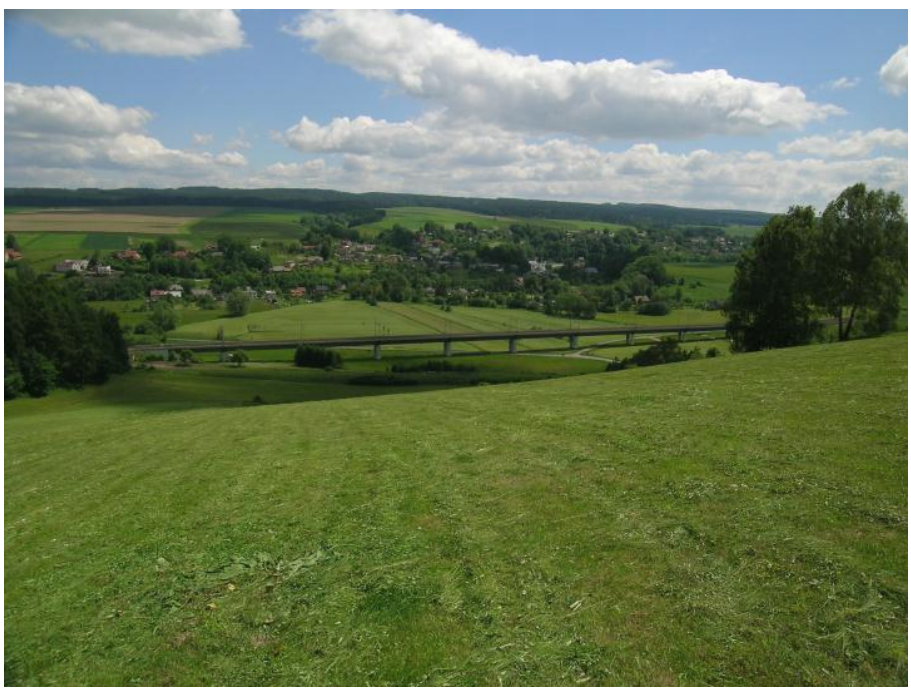




\section{Soil characteristics}

The methodology of soil sampling and their analyses followed Kubíková (1971) and Suchara (2007). One-off soil sampling from all plots was carried out during September 15th, 2006. Mixed soil samples (ca $2 \mathrm{dm}^{3}$ ) for each plot was taken from the root layer (ca $15-20 \mathrm{~cm}$ ) in two spots within the area of the square. After drying up they were sifted through sieve ( $2 \mathrm{~mm}$ mesh diameter) to obtain homogenous material for analyses. Samples were placed in aluminium weighing bottles for immediate moisture and sampling cylinders for capillary capacity. The analyses involved 6 basic soil characteristics: (1) immediate weight moisture content of the soil, (2) maximum water capillary capacity, (3) conductivity, (4) soil reaction $(\mathrm{pH}),(5)$ total nitrogen content, and (6) total carbon content.

The immediate moisture was determined gravimetrically using aluminium drying bowls. Maximum capillary capacity was determined by a modified method by Novák (Kubíková (1971), using sampling cylinders with precisely defined volume $\left(100 \mathrm{~cm}^{2}\right)$. The identified characteristic represents the amount of water which is absorbed by an undisturbed soil sample from water-saturated filter paper. The sample is dried up immediately after saturation $\left(\right.$ at $105^{\circ} \mathrm{C}$ ). The soil reaction of $\mathrm{pH}$ was measured in water extract (extract of fine earth samples in fresh distilled water) with a combined glass electrode. The reaction corresponds to the so-called active reaction. It represents the natural content of currently free hydrogen ions $\left(\mathrm{H}^{+}\right)$and easily water-soluble hydrolysing salts in a soil solution (Suchara, 2007). Conductivity was measured in water extract from samples by conductometer and the data (applied to the temperature of $25^{\circ} \mathrm{C}$ ) was standardly adjusted according to electrode calibration by $\mathrm{KCl}$ solution. The total content of oxidizable carbon was determined by the mineralisation method in the wet way in chrome-sulphur mixture. An equivalent surplus of Mohr's salt (ammonium iron sulphate) was added to the nonreactant remnant of bichroman $\left(\mathrm{K}_{2} \mathrm{Cr}_{2} \mathrm{O}_{7}\right)$ and the surplus of $\mathrm{Fe}^{+}$was determined through titration with bichroman. The total content of nitrogen was determined by the distillation method according to Kjedahl, using the automatic distilling machine Büchi. The contained nitrogen was converted to the ammonium form through the wet mineralisation method using sulphuric acid with catalyzer and thermoregulation salt (mixture $\mathrm{CuSO}_{4}+$ $\left.\mathrm{Na}_{2} \mathrm{SO}_{4}\right)$. The ammonia was displaced with a surplus of lye $(\mathrm{NaOH})$ and it was distilled as ammonium hydroxide into boric acid. The solution was back-titrated using $0.05 \mathrm{~N}$ hydrochloric acid.

\section{Numerical vegetation classification}

Relevés were processed in the TURBOVEG program, version 2.0 (Hennekens, 1995, Hennekens et Schaminée, 2001) and afterwards evaluated using the JUICE program, version 6.3 (Tichý, 2002). The divisive polythetic classification TWINSPAN (Hill, 1979), which is an integral part of the JUICE software (Tichý, 2002, Tichý et Holt, 2006), was used for the initial division of the relevés into groups based on similarity in species composition. The compositional similarity of relevés is measured by three similarity indices based on fidelity and frequency (Tichý et Holt, 2006). The acquired overview of diagnostic, constant and dominant species after the synoptic table analysis was taken into account when arranging the relevés into phytosociological units.

All relevés were classified without bryophytes (data on their species composition was not complete for all relevés). Relevés from transects were analysed separately from relevés obtained from permanent plots. Relevés from permanent plots taken in particular years were analysed together. The resultant classification groups (clusters) represented individual syntaxa. The way the relevés recorded on the same plot were ranked in these syntaxa reflected possible changes in species composition over time. 
The final classification of grassland communities in the locality was based on the revised system of vegetation classification (Chytrý et al., 2007). Studies by Balátová-Tuláčková (1972, 1976, 1981), Blažková (1973), Rybníček et al. (1984), Rychnovská et al. (1985), Neuhäusl et Neuhäuslová (1989), Moravec et al. (1995), Botta-Dukát et al. (2005) were drawn upon in a smaller degree.

\section{Multidimensional statistical analysis (ordination)}

The acquired data about the species and environmental variables from transects and permanent plots were analysed using multidimensional statistical methods - the direct and indirect gradient analysis - in the CANOCO software (Ter Braak et Šmilauer, 1998).

We used 42 relevés from 2005 for analysis of transect data. Environmental variables included: altitude, slope (categorical variable coded for three intervals in the range of values, where value 0 represents the slope inclination up to $5^{\circ}$, value 1 for slope in the range $5-10^{\circ}$, and value 2 for slope above $10^{\circ}$ ), management (categorical variable cut/uncut), immediate moisture, maximum water capillary capacity, total nitrogen content, total carbon content, the $\mathrm{C}: \mathrm{N}$ ratio, $\mathrm{pH}$ and conductivity.

Indirect linear principal components analysis (PCA) was chosen as the first step of the analysis with preset parameters. The output is ordination plots, which show mutual position of particular species and relevés in relation to the calculated gradient represented by ordination axes. The decision of using linear or unimodal analysis was taken on the basis of gradient length in the indirect detrended correspondence analysis (DCA). For resulting gradient length (2.829) linear method is recommended (Lepš et Šmilauer, 2000, Herben et Münzbergová, 2003). Linear redundancy analysis (RDA) was used as a direct ordination method. The preset parameters were preserved in the analysis and the data set was standardised based on species (more importance is given to rare species and species with low cover) and on relevés as well (all records had the same importance). Using the method of forward selection, explanatory variables with the biggest impact on the variability of data were selected. These variables were filtered in the form of covariables and the strength of the remaining explanatory environmental variables was determined. The relative significance of the impact of the environmental variables was tested by the Monte-Carlo permutation test with preset number of permutations (Šmilauer, 1992).

The direct unimodal method canonical correspondence analysis (CCA) was chosen for the analysis of the data from the permanent plots. The time change in the species composition of the permanent plots was tested as year-on-year variability by randomisation with binary coded time (independent variable) and with the plot code (covariables). For temporal analysis we used only years with complete records from all plots, i.e. 1975 and 2005. The analysis thus evaluates time span of 30 years.

\section{RESULTS AND DISCUSSION}

\section{Grassland communities - transect approach}

The set of 42 relevés was divided into 12 clusters (groups of similar relevés) with the help of the TWINSPAN analysis using the given configuration of parameters. The first classification divided the set into two main groups, which according to the moisture gradient belonged either to the upper (rising) or lower (floodplain) part of the meadow complex. In the second step, relevés from the mown part were separated from those from the unmown part in the rising part of the meadow. In the case of the floodplain part we can follow the separation of more mesophilous stands from the hygrophilous ones. From the 
phytosociological point of view the assessed grassland stands correspond to the class Molinio-Arrhenatheretea Tüxen 1937.

The overview of grassland syntaxa on the association and variety levels is as follows:

Class: Molinio-Arrhenatheretea Tüxen 1937

Alliance: Arrhenatherion elatioris Luquet 1926 (syn. Alopecurion pratensis Passarge 1964)

Association Poo-Trisetetum flavescentis Knapp ex Oberdorfer 1957 (syn. Trifolio-

Festucetum rubrae Oberdorfer 1957)

variant Hypericum maculatum

variant Arrhenatherum elatius

Alliance: Calthion palustris Tüxen 1937

Association Cirsietum rivularis Nowiński 1927

variant Poa pratensis

Relevés from the floodplain were all classified as association Cirsietum rivularis Nowiński 1927, though their floristic composition indicates more or less transition between closely related syntaxa. Species composition was considerably depended on the soil water content. Strongly waterlogged sites hosted plant species typical for Cirsietum meadows (Carex sp., Cirsium rivulare, Caltha palustris and others) while drier stands tended to change into mesic Arrhenatherion formations. This type of meadow vegetation is often classified as association Holcetum lanati Issler 1936 which borders upon three alliances: Calthion, Alopecurion pratensis and Arrhenatherion (Moravec, 1995). From ecological point of view indicates Holcetum lanati mostly Calthion alliance (Kovár, 1981). Final classification of relevés was based on frequent occurrence of plant species typical for Cirsietum (Cirsietum rivulare especially).

Grasslands on the slope correspond to association Poo-Trisetetum flavescentis Knapp ex Oberdorfer 1957. Vegetation composition is characteristic of dominance of two grasses Festuca rubra agg. and Agrostis capillaris. Regulary mowed stands were classified as variant Hypericum maculatum with diagnostic species Campanula rotundifolia and Hypericum maculatum, while stands without management were classified as variant Arrhenatherum elatius with diagnostic species Hypericum perforatum.

For species composition of transect relevés see Annex 1.

\section{Numerical and phytosociological classification of permanent plots}

Using the TWINSPAN analysis the relevés were assigned to particular permanent plots and they were divided by time periods according to their mutual similarity into 11 clusters (groups of similar relevés). On the first level the relevé set was divided according to moisture gradient (as in the case of data from transects). One group of relevés represents rather broad-leaved type of stands, the second one comprised mesophilous meadows dominated by Arrhenatherum elatius and plots from drier sites, among which there were also records of ruderal vegetation on the former railway embankment (distinguished by the indicator species of primarily ruderal plants like Agropyron repens, Arabidopsis thaliana, Capsella bursa-pastoris, Matricaria chamomilla and others). Distinct cluster of sedge stands within the first group of communities was separated belonging to the Caricion gracilis alliance. A group of ruderal vegetation relevés evolved under the disturbance during construction works was recorded, too. Finer division and details of records are mentioned below. 


\section{Class: Phragmiti-Magnocaricetea Klika 1941}

Alliance: Caricion gracilis Neuhäusl 1959 em. Balátová-Tuláčková 1963

Association Caricetum gracilis Almquist 1929

Association Caricetum acutiformis Eggler 1933

\section{Class: Scheuchzerio-Caricetea fuscae Tüxen 1937}

\section{Alliance: Caricion davallianae Klika 1934}

Association Valeriano dioicae-Caricetum davallianae (Kuhn 1937) Moravec in Moravec et Rybníčková 1964

\section{Class: Molinio-Arrhenatheretea Tüxen 1937}

Alliance: Arrhenatherion elatioris Luquet 1926 (syn. Alopecurion pratensis Passarge 1964)

Association Poo-Trisetetum flavescentis Knapp ex Oberdorfer 1957 (syn. Trifolio-

Festucetum rubrae Oberdorfer 1957)

variant Arrhenatherum elatius

variant Sanguisorba officinalis

Alliance: Deschampsion cespitosae Horvatić 1930 (syn. Alopecurion pratensis Passarge 1964)

Association Holcetum lanati Issler 1934

variant Carex hirta

Alliance: Calthion palustris Tüxen 1937

Association Cirsietum rivularis Nowiński 1927

variant Carex flava

Ruderal vegetation on the embankment and the vegetation of strongly disturbed sites were difficult to classify in terms of traditional phytosociological classification - they were not associated to any phytosociological unit. For more information on the results in regard to the indication of site conditions by the studied communities see the study Jandová (2007).

For species composition of permanent plot relevés see Annex 2.

It can be surprising that all 42 transect records sampled in variable environmental conditions is classified to two associations only in spite of higher phytocenological variability reflected by permanent plots (transects do not cover two classes - PhragmitoMagnocaricetea and Scheuchzero-Caricetea fuscae nor alliance Deschampsion cespitosae). More detailed view shows that it the cause is different temporal scale of both data collections: permanent plots includes the extinct communities in older time horizons (e.g. Scheuchzerio-Caricetea fuscae). Another reason consists in the design of sampling plots their density doesn't cover fragmented or marginal stands, e,g. Phragmito-Magnocaricetea).

\section{Ordination of transect data}

The indirect gradient method was used to get an initial idea of the variability in the evaluated set of relevés. The results of the PCA analysis are shown in the ordination join plot using visualisation for samples (Fig. 2). The interpretation is limited to the first two axes. These explain $38.5 \%$ of variability (the first axis explains $28.8 \%$, the second $9.7 \%$ ). 
Grouping of relevés indicate well coincidence with the habitat moisture. The environmental gradient is represented by the first ordination axis: on the right (group „, $\mathrm{B}$ “) there are relevés from the wet floodplain part of the catena and on the opposite side (group „A" and „C") there are relevés of dry hillside positions. The second ordination axis represents the management gradient and reflects the difference between cut and uncut stands. The relevés in the bottom part of the graph are characteristic by higher abundance of species which react positively to frequent disturbance by cutting (there are some grasses and hemicryptophytes with a leaf rosette).

Fig. 2: Results of indirect gradient analysis (PCA) for transect data - ordination graph for samples

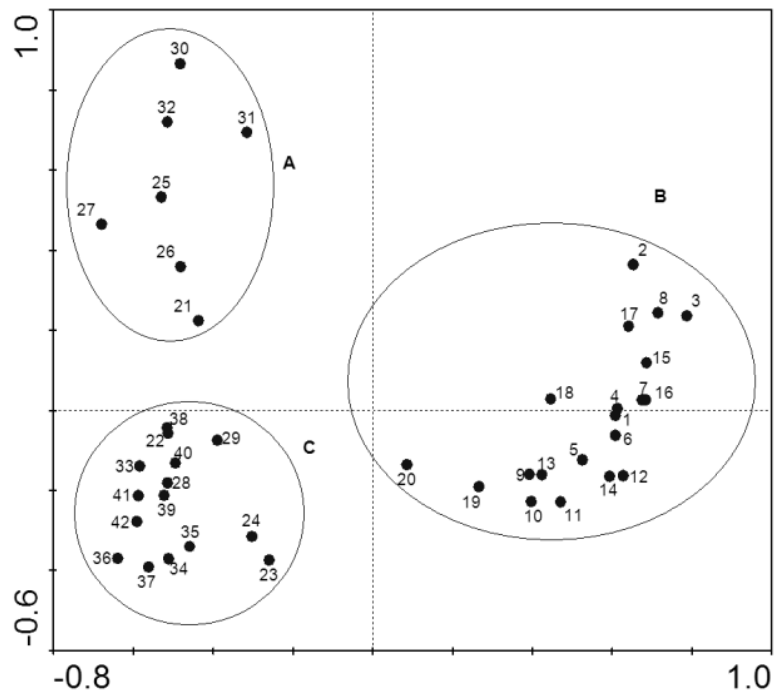

Note: The oval „A“ indicates relevés of uncut stand, the oval „B“ indicates relevés from the alluvial position, the grouping of the relevés in oval „C" corresponds to cut stands of hillside positions. (according to Jandová, 2007)

\section{Community - environment relationships}

The direct analysis method tested the relations between species composition and specific environmental conditions directly related to individual vegetation records. The results of the correlation of individual species to environmental parameters are presented in the form of a diagram in Fig. 3 (all environmental variables) and Fig. 4 (environmental variables remained after filtering covariables). The numerical output is summed up in Tab. 1. For specific values of environmental variables see Jandová (2007). 
Table 1: Results of direct gradient analysis RDA from transect data

\begin{tabular}{|lccccccc|}
\hline RDA analysis & $\begin{array}{c}\text { 1st axis } \\
\text { \% sp }\end{array}$ & $\begin{array}{c}\text { 1st axis \% } \\
\text { sp-en }\end{array}$ & $\begin{array}{c}\text { 2nd axis } \\
\text { \% sp }\end{array}$ & $\begin{array}{c}\text { 2nd axis } \\
\text { \% sp-en }\end{array}$ & \% in total & F & p \\
\hline $\begin{array}{l}\text { all environmental } \\
\text { variables }\end{array}$ & 12.6 & 32.8 & 18.6 & 48.8 & 38.5 & 1.942 & 0.002 \\
\hline $\begin{array}{l}\text { environmental } \\
\text { variables without } \\
\text { covariables }\end{array}$ & 6.3 & 33.6 & 10.3 & 54.9 & 75.7 & 1.436 & 0.002 \\
\hline
\end{tabular}

(\% sp. 1st axis (resp. \% sp 2nd axis) - cumulative percentage of species variability explained by the first (resp. second) ordination axis; \% sp-en 1st axis (resp. \% sp-en 2nd axis) - cumulative percentage of species variability relative to all included environmental variables explained by the first (resp. second) ordination axis; \% in total - percentage of variability explained by the given model; $F$ and $p$ - criterion and level of significance of the Monte-Carlo permutation test) (according to Jandová, 2007)

When all variables were included, it became apparent that water capillary capacity, altitude and slope inclination have the biggest impact on vegetation composition. The least impact had C: $\mathrm{N}$ ratio. The first two ordination axes cover $18.6 \%$ of variability ( $1^{\text {st }}$ axis 12,6 $\%, 2^{\text {nd }}$ axis $6 \%$ ). Gradual filtering of variables demonstrated that the largest share of data variability was accounted for by altitude, inclination, cutting and water capillary capacity (75\% of variability relative to variability explained by all environmental variables). Following covariables were chosen: altitude, inclination, moisture, water capillary capacity and conductivity. The first ordination axis in the model without covariables accounted for $6.3 \%$ of variability (a third in comparison with the total model). The first two axes together accounted for $10.3 \%$. Based on a correlation matrix it is possible to consider cutting and $\mathrm{pH}$ as variables of higher improtance then the others.

A positive correlation between the current soil moisture, capillary capacity, nitrogen and carbon content, conductivity and $\mathrm{pH}$ is evident from the mutual position of individual environmental variables (Fig. 3). The values of soil characteristics correspond to this. Soils in the alluvium are heavier than in hillside positions, they have bigger moisture-holding capacity and slightly higher $\mathrm{pH}$. The conditions are also reflected in species composition of communities: the more fertile and wetter alluvial soils host eutrophic Cirsium stands, whereas more acid oligotrophic slope site is also occupied by elements of acidophile dry lawns. The high $\mathrm{C}: \mathrm{N}$ ration correlates with the occurrence of some species of more advanced successional phases when the site is not cut. This is accompanied by overgrowing and accumulation of litter. Altitude and slope inclination are negatively correlated to all mentioned variables (except $\mathrm{C}: \mathrm{N}$ variables). This is caused by their being connected due to the topography of the terrain. Altitude basically represents the distance from the flat lowland, i.e. from the source of moisture (position on the transect), which turned out to be the main gradient in the species composition of grassland communities.

The gradient of management (more precisely mowing versus absence of mowing - i.e. successional overgrowth) became evident in the diagram of the species dependency and remaining environmental variables (Fig. 4). The species position in the space between the axes shows an increased concentration of species characteristic for phases of successional development. These species in effect 'cause' the existence of the gradient because the spaces in the unmown part of the grassland differ greatly in species composition from the remaining cut areas. Prunella vulgaris, species with leaf rosettes (Plantago lanceolata, Taraxum sect. Ruderalia), Leucanthemum vulgare and Holcus lanatus are closest to the centroid. The interpretation of $\mathrm{pH}$ and total nitrogen and carbon is more complicated. Due 
to the generally narrow range of $\mathrm{pH}$ values in the locality this parameter does not reveal so much.

\section{Fig. 3: Results of direct gradient analysis (RDA) for transect data - species and environmental variables.}

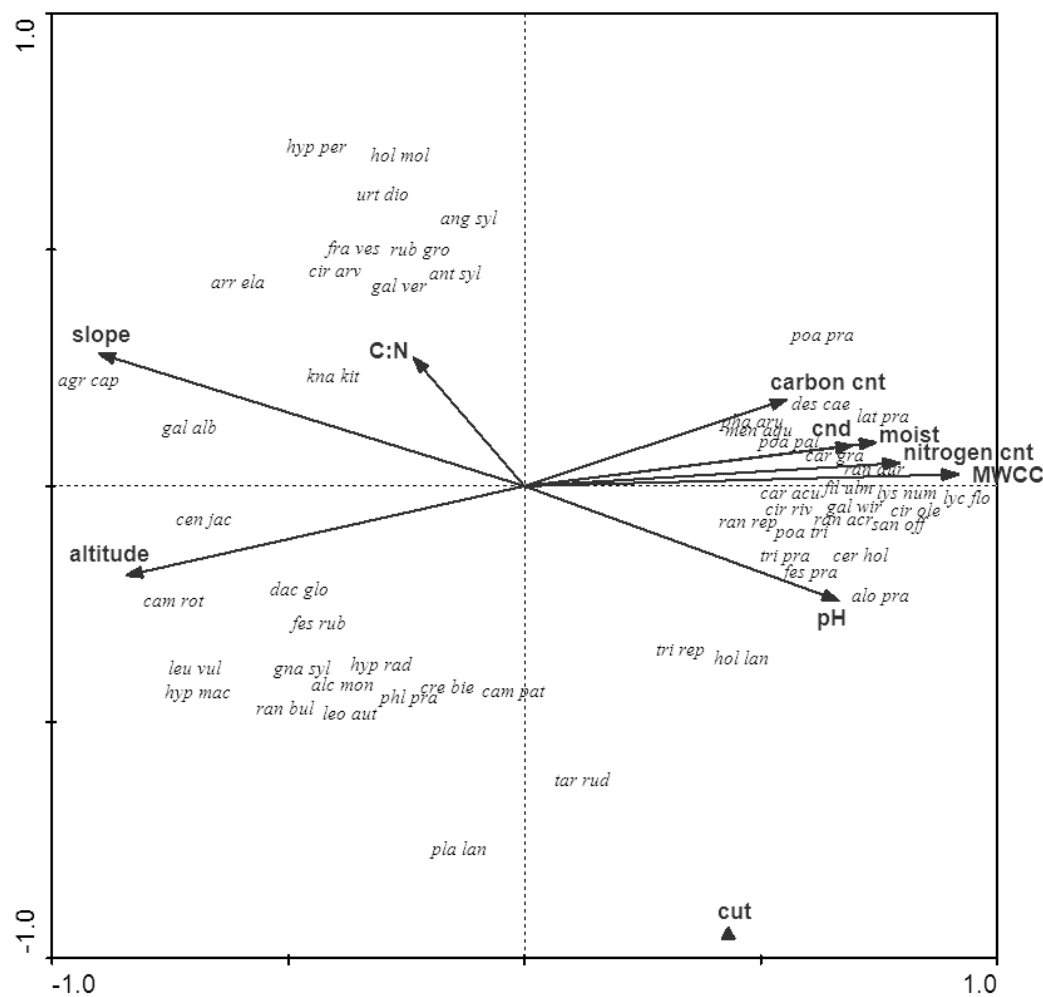

Note: Quantitative environmental variables are indicated by arrows. The value increases in the direction of the arrow. Nominal variables are represented by points. The value is the highest around points. Mutual orientation of arrows indicates their mutual correlation: narrow angle - positive; right angle - independent; opposite orientation - negative. Carbon cnt - carbon content, nitrogen cnt nitrogen content, $\mathrm{C}: \mathrm{N}$ - carbon-nitrogen ratio, cnd - conductivity, moist - immediate moisture, MWCC- maximum water capillary capacity.

Key to abbreviations of species used in Fig. 3: agr cap - Agrostis capillaris, alc mon-Alchemilla monticola, alo pra-Alopecurus pratensis, ant syl - Anthriscus sylvestris, ang syl-Angelica sylvestris, arr ela - Arrhenatherum elatius, cam pat - Campanula patula, cam rot - Campanula rotundifolia, car acu-Carex acutiformis, car gra Carex acuta, cen jac - Centaurea jacea, cer hol-Cerastium holosteoides, cir arv-Cirsium arvense, cir ole Cirsium oleraceum, cir riv - Cirsium rivulare, cre bie - Crepis biennis, dac glo - Dactylis glomerata, des cae Deschampsia cespitosa, fes pra - Festuca pratensis, fes rub - Festuca rubra, fil ulm - Filipendula ulmaria, fra ves - Fragaria vesca, gna syl - Gnaphalium sylvaticum, hol mol - Holcus mollis, hol lan - Holcus lanatus, hyp per - Hypericum perforatum, hyp mac - Hypericum maculatum, hyp rad - Hypochaeris radicata, gal alb Galium album, gal ver - Galium verum, gal wir - Galium wirtgenii, kna kit - Knautia kitaibelii, lat pra Lathyrus pratensis, leo aut - Leontodon autumnalis, leu vul - Leucanthemum vulgare, lyc flo - Lychnis floscuculi, lys num - Lysimachia nummularia, men aqu - Mentha aquatica, pha aru - Phalaris arundinacea, phl pra - Phleum pratense, pla lan - Plantago lanceolata, poa pal - Poa palustris, poa pra - Poa pratensis, poa tri-Poa trivialis, ran acr-Ranunculus acris, ran aur - Ranunculus auricomus, ran bul - Ranunculus bulbosus, ran rep Ranunculus repens, rub gro - Rubus grossus, san off - Sanguisorba officinalis, tar rud - Taraxacum sect. Ruderalia, tri rep - Trifolium repens, tri pra- Trifolium pratense, urt dio - Urtica dioica, ver off - Veronica officinalis) (according to Jandová: 2007) 


\section{Fig. 4: Results of direct redundancy analysis (RDA) for transect data - species and environmental variables (without covariables).}

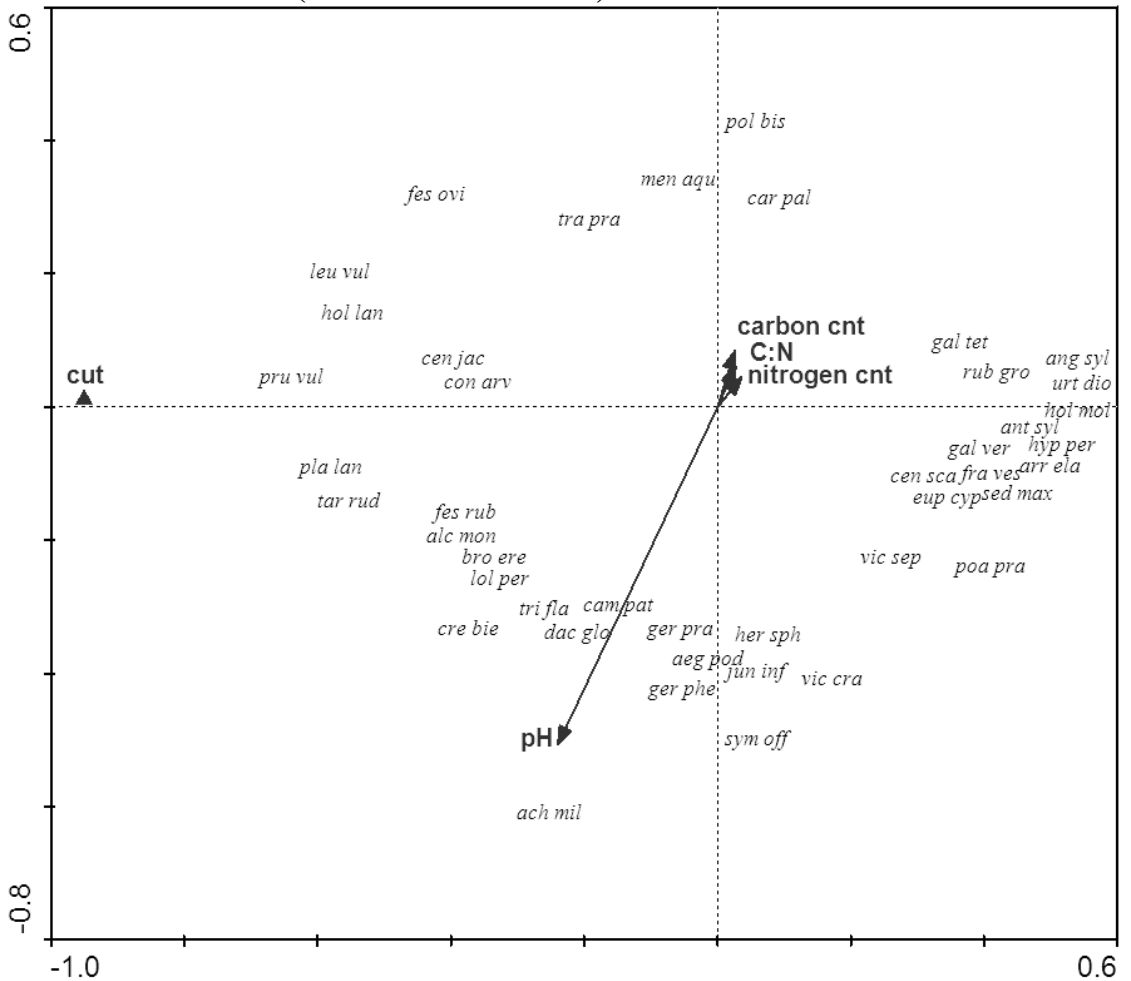

Note: Quantitative environmental variables are represented by arrows - the value increases in the direction of the arrow. Nominal variables are represented by points. The value is the highest around points. Mutual orientation of arrows indicates their mutual correlation: narrow angle - positive; right angle - independent; opposite orientation - negative. Species abundance increases in the direction of the arrow. Carbon $\mathrm{cnt}$ - carbon content, nitrogen $\mathrm{cnt}$ - nitrogen content, $\mathrm{C}: \mathrm{N}$ - cabon-nitrogen ratio.

Key to abbreviations of species used in Fig. 4: aeg pod-Aegopodium podagraria, ach mil-Achillea millefolium, alc mon - Alchemilla monticola, ant syl - Anthriscus sylvestris, ang syl - Angelica sylvestris, arr ela - Arrhenatherum elatius, bro ere - Bromus erectus, cam pat - Campanula patula, car pal-Carex pallescens, cen jac - Centaurea jacea, cen sca - Centaurea scabiosa, con arv - Convolvulus arvensis, cre bie - Crepis biennis, dac glo - Dactylis glomerata, eup cyp - Euphorbia cyparissias, fes ovi- Festuca ovina, fes rub - Festuca rubra, fra ves - Fragaria vesca, gal tet - Galeopsis tetrahit, gal ver - Galium verum, ger pha - Geranium phaeum, ger pra-Geranium pratense, her sph-Heracleum sphondyllium, hol mol - Holcus mollis, hol lan - Holcus lanatus, hyp per-Hypericum perforatum, jun inf - Juncus inflexus, leu vul - Leucanthemum vulgare, lol per-Lolium perenne, men aqu - Mentha aquatica, pla lan-Plantago lanceolata, poa pra-Poa pratensis, pol bis - Bistorta major, pru vul - Prunella vulgaris, rub gro - Rubus grossus, sed max - Hylotelephium maximum, sym off Symphytum officinalis, tar rud - Taraxacum sect. Ruderalia, tra pra - Tragopogon pratensis, tri fla - Trisetum flavescens, urt dio - Urtica dioica, vic cra - Vicia cracca, vic sep - Vicia sepium)

(according to jandová: 2007)

\section{Permanent plot approach and vegetation temporal changes}

Data from permanent plots were analysed using the direct unimodal method canonical correspondence analysis (CCA). Time was the tested independent variable (the change between 1975 and 2005 for nine fixed plots; the tenth plot on the railway embankment was not included in the analysis as there was no comparative relevé from 1975). Every plot was 
assigned covariables, which removed variability between plots (the choice in the program unrestricted permutations within blocks defined by covariables). The relative significance of the impact of the environmental variable (time) was tested by Monte-Carlo permutation test (preset number of permutations). The results are summed up in Tab. 2.

Table 2: Results of direct unimodal analysis CCA for data from fixed plots (\% sp. 1st axis (resp. \% sp 2nd axis) - cumulative percentage of species variability explained by the first (resp. second) ordination axis; total variability - variability explained by the given model; $\mathrm{F}$ and $p$ - criterion and level of significance of Monte-Carlo permutation test.)

\begin{tabular}{|ccccccc|}
\hline CCA analysis & $\begin{array}{c}\text { 1st axis } \\
\text { \% sp }\end{array}$ & $\begin{array}{c}\text { 2nd axis } \\
\text { \% sp }\end{array}$ & total variability & F & p \\
\hline 14.4 & 37.5 & 3.196 & 1.347 & 0.004 \\
\hline
\end{tabular}

(according to JANDOVÁ, 2007)

Fig. 5: Results of direct correspondance analysis (CCA) for data from fixed plots species and relevés.

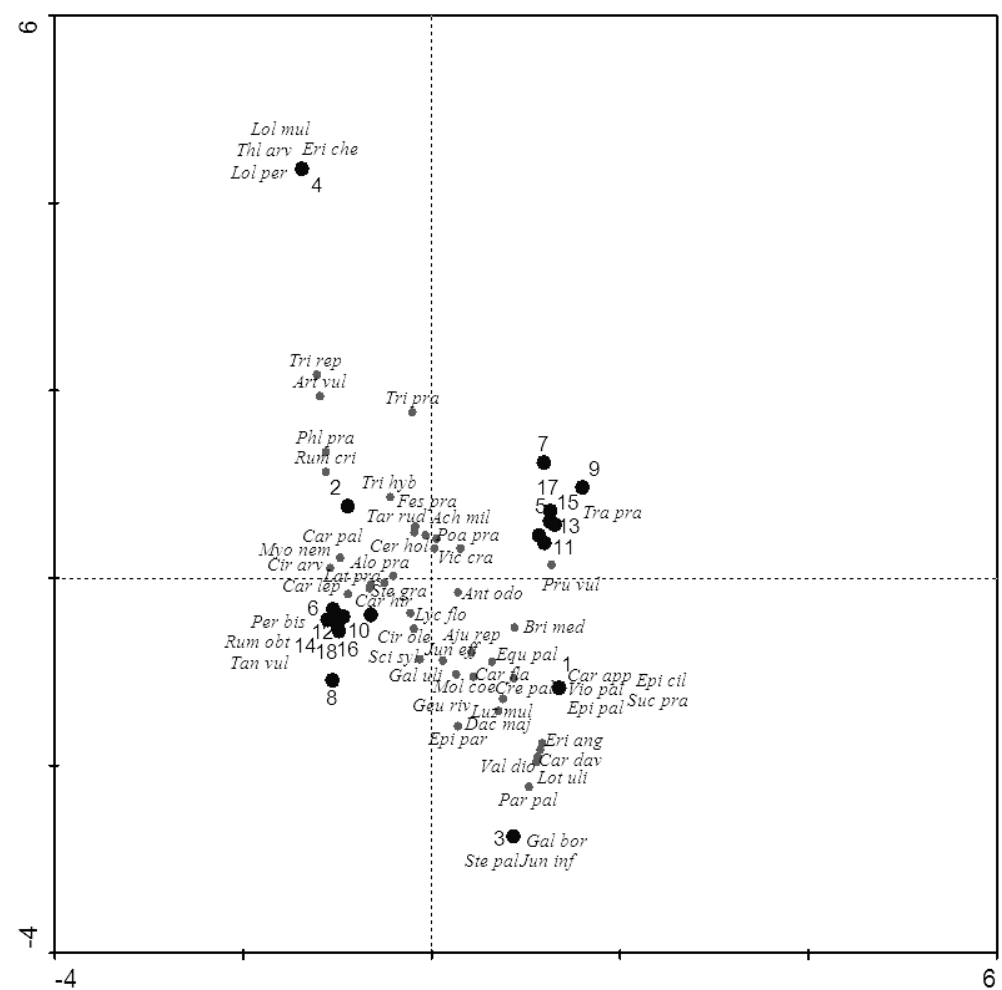

(Pairs of relevés from fixed plots - the first from 1975, second from 2005: T/1 (1/2), T/II (3/4), T/III (5/6), T/IV (7/8), T/V (9/10), T/VI (11/12), T/VII (13/14), T/VIII (15/16), T/IX (17/18). 
Key to the abbreviations of the species in Fig. 5: ach mil - Achillea millefolium, aju rep - Ajuga reptans, alo pra-Alopecurus pratensis, ant odo-Anthoxanthum odoratum, art vul-Artemisia vulgaris, bri med - Briza media, car app - Carex appropinquata, car dav-Carex davalliana, car fla-Carex flava, car hir-Carex hirta, car lep - Carex leporina, car pal - Carex pallescens, cer hol-Cerastium holosteoides, cir arv-Cirsium arvense, cir ole - Cirsium oleraceum, cre pal - Crepis paludosa, dac maj-Dactylorhiza majalis, equ pal Equisetum palustris, epi cil - Epilobium ciliatum, epi pal - Epilobium palustre, epi par - Epilobium parviflorum, eri ang - Eriophorum angustifolium, eri che - Erysmum cheiranthoides, fes pra - Festuca pratensis, gal bor Galium boreale, gal uli - Galium uliginosum, geu riv-Geum rivale, jun eff - Juncus effusus, jun inf - Juncus inflexus, lat pra - Lathyrus pratensis, lol mul - Lolium multiflorum, lol per - Lolium perenne, lot uli - Lotus uliginosus, luz mul - Luzula multiflora, lyc flo - Lychnis flos - cuculi, mol coe - Molinia coerulea, myo nem Myosotis nemorosa, per bis - Bistorta major, phl pra - Phleum pratense, poa pra - Poa pratensis, rum criRumex crispus, rum obt - Rumex obtusifolius, sci syl - Scirpus sylvaticus, ste gra - Stellaria graminea, ste pal Stellaria palustris, tan vul - Tanacetum vulgare, tar rud - Taraxacum sec. ruderalia, thl arv - Thlaspi arvense, tra pra - Tragopogon pratensis, tri hyb - Trifolium hybridum, tri pra - Trifolium pratense, tri rep - Trifolium repens, val dio - Valeriana dioica, vic cra - Vicia cracca, vio pal - Viola palustris)

(according to Jandová: 2007)

Time accounted for $5.6 \%$ of total variability of the data set without covariables (the impact of the plot). In all $9 \%$ of the variability of the data set is covered by the first two axes. It is evident from the results of the permutation test that the difference is significant. There was significant change in the vegetation structure during time in the studied plots. In the ordination graph (Fig. 5) older relevés from 1975 are concentrated in the right part, the new ones from 2005 are on the left. The most distant (and the least similar) are the relevés 3 and 4 from the fixed plot T/II, which was completely destroyed during the construction of the railway flyover. While in the original state in 1975 the relevé in the ordination diagram is surrounded by species of the Caricion davallianae alliance, in 2005 this relevé can be found in part of the graph, typical for ruderal and sown species (Lolium spp.).

\section{Environmental threat and threaten communities or species}

We focused on communities, vegetation types, biotopes and plant species limited occurrence in the site, directly threatened or even irretrievably lost. A broader phytosociological framework of the occurence of taxa or also syntaxa in the region was compared with available information sources (Domin, 1942a, 1942b, Kovár et al., 1996, Prausová, 2002, Málková, 2006) and our field experience. Threatening trend is represented by increase of new disturbed sites along the railway corridor by ruderalisation at the landscape level (e.g. fixed plot T/X on the former railway embankment), that means open space for dispersal of invasive and expansive weeds and their communities (Kovár et Lepš, 1986).

The rarest community mapped in the locality in 1975 (Kovár̆, handwritten records) were short-leaf sedge communities of the Caricion davallianae alliance Klika 1934, association Valeriano-Caricetum davallianae Kuhn 1937, Moravec in Moravec et Rybníčková 1964. Its occurence was not confirmed even before the beginning of construction works in 2001. Therefore it is possible to conclude that the community has not occurred in the locality for a number of years. Probably due to eutrophication in both site fragments over the last decades there was a change from fen short-leaf vegetation to tall-stem Cirsium meadows. From the rare species typical for this community, only individuals of Carex appropinquata, Carex flava, Carex tomentosa, Crepis mollis subsp. hieracioides, Dactylorhiza majalis (orchid from the list of CITES species), Epilobium parviflorum, Galium boreale, Geum rivale, Selinum carvifolia, Stellaria palustris, Valeriana dioica, Veronica scutellata and Viola palustris have been found over the last five years. All species occurred only sporadically either as individuals or a small, declined population with a substantially limited cover. 
The sedge Carex davalliana dominant in the site in 1975, was not recorded in 2005 in the whole locality at all. Botanical surveys conducted over the last few years have revealed that Carex davalliana has more or less disappeared from the territory of the phytosociological district Bohemian-Moravian Highlands although in mid $20^{\text {th }}$ century it was abundant everywhere on waterlogged meadows (Domin, 1942a). The author mentions specifically the record in the vicinity of Česká Třebová (Semanín village) from 1892 by F. Maloch, which was confirmed by Kovár (1978) in the 1970s. Currently Carex davalliana survives in a limited number of localities in the region-(documented by Kovár, 1972). Dactylorhiza majalis grew in 2005 on a small part of the site-in a depression close to the embankment, where six flowering specimens were found. Although in 2008 this part of the floodplain was devastated by the removal of the upper level of the soil, surrounded by a drainage ditch and covered with gravel and other materials, one more specimen of the orchid Dactylorhiza majalis bloomed on the eastern margin.

Parnassia palustris was in the 1970s still common in almost all the territory of the Czech Republic. However, due to human activity it has been receding substantially over the last few decades. Similar development can be also seen in the species Succisa pratensis and Geum rivale, which occur in alternatively wet meadows and pastures. Due to their dependence on biotopes, which had often changed on a big scale (especially by drainage but also by ploughing the wet meadows), they became markedly less common. In some localities they disappeared completely. The species Epilobium palustre and E. parviflorum are also on the decline for the same reasons (Slavík, 1997). All four species mentioned above were not only recorded in the locality but also mapped in wider surroundings of Česká Třebová (Domin, 1942a, 1942b).

The most threatened biotope was calcareous fen - recorded in two microlocalities within the lowland grassland complex. Change in species composition, disappearance of some rare species and reduced occurrence of some other species were mainly the consequence of changes in the water regime of the sites, intensive exploitation and the use of heavy machinery. Other factors include washing up nutrients from the surroundings and probably fertilisation. This is indicated by the occurrence of more nitrophilous species and species connected with a more fertile site (eutrophic stands with Cirsium rivularis). In connection with this there may also have been changes in the soil reaction, i.e. a shift to more acid environment. Field research showed that the biotope is completely beyond the possibility of a restoration. Mesophilous and - on a reduced scale - eutrophic ecotopes with stands of the Calthion alliance are of high quality in regard to biotic functions in the landscape, which include overall species diversity and the presence of threatened and typical species. Cirsium stands in the locality are in various stages of transition to other, rather mesophilous vegetation types and typical species composition is limited to small refuges. The main reason for these changes is drainage of farmed plots by ditches, which lowers groundwater table, reduces the moisture of the root area in the soil profile and thus causes a higher content of nutrients, brought about by more intensive mineralisation (Schrautzer et al., 1996, Tallowin et Smith, 2001). Arrhenatherum and Festuca stands are especially threatened if they are not regularly mown. They tend to overgrow quickly with self-sown woody species and shrubs and are easily invaded by undesirable species and species that have a competitive advantage (with clonal growth, tall species, species tolerant to a higher nitrogen content etc.).

The stand of Cirsium meadows of the association Cirsietum rivularis Nowiński 1927, which arose successionally under the influence of eutrophication from the previous community of the Valeriano-Caricetum davallianae association, is also currently spatially restricted in the locality. The value and importance of the community increases with the 
presence of rare and less common species which have survived in it (e.g. the discovery of Eriophorum angustifolium or Lotus uliginosus in 2005, not confirmed in 2007).

The more oligotrophic subunit of the Arrhenatherion alliance, meadows of the association Poo-Trisetetum flavescentis Knapp et Oberdorfer 1957 represents transitional mesophilous type of the alliance. It occupies the foot of the hillside. The community does not host - with the exception of Gentianopsis ciliata - vascular plants valuable from the nature conservation point of view. The species Gentianopsis ciliata occurs in a larger territory in the region on dry sites (Domin, 1942a, Kovár. 1972) and it is still relatively frequent. This relatively species rich meadow community could be degraded under the influence of increasing eutrophication, introduction by expansive species and secondary succession when management has declined (Chytrý et al., 2007).

Besides the grassland communities it is also desirable to pay attention to wetland biotopes of the Caricion gracilis Neuhäusl 1959, the tall sedge vegetation. Fragmentary stands of Caricetum acutiformis Eggler 1993 and Caricetum gracilis Almquist 1929 were mapped in the locality, in the bank zone of the ditch with stagnant water. Their dominant species are important especially for regulation of the water regime in the landscape. Some important environmentally indicative wetland species occur in these communities such as Ranunculus flammula, Veronica scutellata, Agrostis canina and Carex nigra.

\section{Management proposals}

Well chosen management of described grasslands should integrate at least practices of maintaining the existing water regime and biomass removal (mowing for hay production). (Schrautzer et al., 1996) listed following measures for improvement of the current state or directly for a renewal of the degraded sites: changes in groundwater dynamics, changes in the production of the phytomass, changes in the nutrient cycle and restoration of typical species composition. Three main factors are usually considered: succession, eutrophication and the expansion of expansive and invasive species (Sádlo et al. 2004). Another important factor, which plays a role not only in the studied locality, is fragmentation of sites (see e.g. Hooftmann et al., 2003, Diethart et al., 2004, Jersáková et Kindlmann, 2004).

Part of grasslands in the whole locality treated as meadows are maintained in relatively good condition by regular mowing twice a year. Mowing holds back the development of tall and self-sown species and supports species diversity. By harvesting biomass organically bound nutrients are taken from the environment.

\section{SUMMARY}

Vegetation types - present state and comparative view within development: Studied grassland communities correspond phytosociologically to the class MolinioArrhenatheretea Tüxen 1937. The alliance Arrhenatherion elatioris Luquet 1926 mesophilous Arrhenatherum and Festuca meadows - represent stands on the hillside of the catena, lying above the former railway embankment. With its species composition they fall into the association Poo-Trisetetum flavescentis Knapp et Oberdorfer 1957 in two varieties: variant Hypericum maculatum and variant Arrhenatherum elatius. Relevés from the unmown part of the meadow are assigned to the second one. Alliance Calthion palustris Tüxen 1937 occupies the floodplain in the flat depression. Observed stands were ranked into the association Cirsietum rivularis Noviński 1927 of Carpathian wet meadows with Cirsium rivulare. While representative records of the association are spatially restricted to the wettest parts of the site, the majority of the floodplain area is occupied by transitional 
vegetation to rather mesophilous type of grasslands, assigned to the Poa pratensis variety. The results of multidimensional statistical methods showed a clear dependence of species composition on the moisture gradient. The second most important factor of differentiation was presence/absence of mowing during the growing season.

The evaluated vegetation relevés from permanent plots $(1975$ - 2005) covered vegetation types of three phytosociological classes. Within the first class Phragmiti-Magnocaricetea Klika 1941 we identified the vegetation of tall sedges from the alliance Caricion gracilis Neuhäusl 1959 em. Balátová-Tuláčková 1963 with two associations, the association Caricetum gracilis Almquist 1929 and the association Caricetum acutiformis Eggler 1933. The second class Scheuchzerio-Caricetea fuscae Tüxen 1937 includes the vegetation of calcareous fens of the alliance Caricion davallianae Klika 1934 with the rare association Valeriano dioicae-Caricetum davallianae (Kuhn 1937) Moravec in Moravec et Rybníčková 1964. The third class Molinio-Arrhenatheretea Tüxen 1937 contains three alliances: (1) mesophilous meadows of alliance Arrhenatherion elatioris Luquet 1926 with stands of Festuca meadows of association Poo-Trisetetum flavescentis Knapp ex Oberdorfer 1957, divided into two variants - variant Arrhenatherum elatius and wetter, transitional variant Sanguisorba officinalis, (2) floodplain meadows of alliance Deschampsion cespitosae Horvatic 1930 with association Holcetum lanati Issler 1934 in the form of variant Carex hirta, (3) wet Cirsium meadows of alliance Calthion palustris Tüxen 1937 with association Cirsietum rivularis Nowiński 1927 and variant Carex flava.

Direct or indirect impacts of the fly-over construction works (change of terrain, disruption and removal of the surface soil horizons) caused replacement of the original grassland vegetation by newly introduced stand (clover-grass mixture sown) or by various ruderal plant assemblages.

Long-term change of grasslands and values for protection: In 1975 the rare community of short-leaf sedges of alliance Caricion davallianae Klika 1934 occured in the locality in fragments. It hosted some important species from the nature protection viewpoint: Carex appropinquata, Carex davalliana, Carex flava, Dactylorhiza majalis, Eriophorum angustifolium, Lotus uliginosus, Parnassia palustris or Valeriana dioica. The community is now replaced by Cirsium meadows. There is a small population of Dactylorhiza majalis (the CITES species) and some rare species on the brink of extinction. Carex davalliana and Parnassia palustris have already become extinct from the locality. The cause of the decline of this biotope consists in the changes of hydrological conditions on the site, its nutrient enrichment (eutrophication) and lastly also in the fragmentation of the site and its disturbance during construction works. The revitalisation of the former species in the future is not practicable. A relatively rich population of Gentianopsis ciliata occurs in hillside positions representing an example of rare and valuable species.

Management of grassland stands: The current management of meadow species is appropriate. The meadows are mown twice a year. This reduces the occurrence of tall species and keeps species diversity on a relatively high level. Cutting and/mowing of the slope vegetation defends spreading of expansive plant species and rooting of self-sowing woody species. Mown biomass is dried on the spot and then taken away. The lowland area is drained by several surface ditches, which gives advantage to mesic meadow grasses and herbs. We propose to add following management measures: (a) control of margins of stands with expansive species and self-sowing woody species, (b) removal of invasive species which can spread along the stream, road and along the railway embankment, (c) keeping the current isolated groups of trees as they represent an effective protection of the hillside 
against negative effects of erosion, (d) keeping sedge stands along the stream, (e) monitoring rare and protected species, support their survival and potentially increase the size of their population. In the case of the population of the protected Dactylorhiza majalis (the CITES species) it would be desirable to take the plot with its occurrence out of the agriculture cooperative's hands and to ensure its protection and maintenance by manual cutting.

\section{REFERENCES}

Balátová-Tuláčková, E. (1972). Flachmoorwiesen im mittleren und unteren Opava-Tal (Schleisen). Vegetace ČSSR, A4, Academia, Praha, 201 p.

Balátová-Tuláčková, E. (1976). Rieder- und Sumpfweisen der Ordnung Magnocaricetalia in der Záhorie-Tiefebene und dem nördlich angrenzenden Gebiete (Synökologische Studie der Magnocaricetalia-Gesellschaften). Vegetácia ČSSR, B3, Veda, Bratislava, 258 p.

Balátová-Tuláčková, E. (1981). Phytozönologische und synökologische Charakteristik der Feuchtwiesen NW-Böhmens. Rozpravy ČSAV, ̌̌ada matematických a př́rodních věd, 91(2), Academia, Praha, 91 p.

Blažková, D. (1973). Pflanzensoziologische Studie über die Wiesen der Südböhmischen Becken. Studie ČSAV č. 10, Academia, Praha, 170 p.

Botta-Dukát, Z., Chytrý, M., Hájková, P. \& Havlová, M. (2005). Vegetation of lowland wet meadows along a climatic continentality gradient in Central Europe. Preslia 77: 89-111. Praha.

Braun-Blanquet, J. (1928). Pflanzensociologie. Grundzuge die Vegetationskunde. Springer Verlag, Berlin, 330 p.

Chytrý, M. (2000). Formalizované přístupy k fytocenologické klasifikaci vegetace. Preslia, 72(1), 1-29.

Chytrý, M. (2007). Vegetace České republiky: 1. Travinná a keříčková vegetace. Academia, Praha.

Diethart, M. (2004). Population size and the risk of local extinction: empirical evidence from rare plants. Oikos, 105, p. 481-488.

Domin, K. (1942a). První př́spěvek k poznání květeny povodí Tiché Orlice u Ústí nad Orlicí, v údolí Třebovky u České Třebové a na Litomyšlsku. Věstník Král. Čes. Spol. Nauk., Tr̆. 2, (1), 1-59. Praha

Domin, K. (1942b). Druhý příspěvek k poznání květeny povodí Tiché Orlice u Ústí nad Orlicí, v údolí Třebovky u České Třebové a na Litomyšlsku. Věstník Král. Čes. Spol. Nauk., Tř. 2, (7), 1-54. Praha

Faltysová, H., Bárta, F. (2002). Chráněná území ČR, svazek IV, Volume IV: Pardubicko, Agency of nature and landscape protection, Eko Centrum Brno, Praha

Hejný, S., Slavík, B. (1988). Květena České republiky. Academia, Praha.

Hennekens, S. M. (1995). TURBO(VEG). Software package for input, processing and presentation of phytosociological data. User's guide. Institut voor Bos en Natuur, Wageningen and Unit of Vegetation Science, University of Lancaster, Lancaster.

Hennekens, S. M., Schaminée, J.H.J. (2001). TURBOVEG, a comprehensive data base management system for vegetation data. J. Veg. Sci., 12, p. 589-591. 
Herben, T., Münzbergová, Z. (2003). Zpracování geobotanických dat v př́kladech, část I. Data o druhovém složení, skriptum PřF UK,. Scriptum, Charles University in Prague, Faculty of Science. Praha.

Hill, M.O. (1979). Twinspan. A Fortran program for arranging multivariate data in an ordered two-way table by classification of the individuals and attributes, Cornell University, Ithaca.

Hooftman, D.A.P. (2003). Genetic effects of habitat fragmentation on common species of Swiss fen meadows. Conservation Biology, 18(4), p. 1043-1051.

Jandová L. (2007). Změny travinných ekosystémů v prostoru železniční stavby. Krajinněekologická prípadová studie: Estakáda u Dlouhé Třebové, Eastern Bohemia, Czech Republic.- Ms. [Dipl. Pr., Depon. in Knih. ÚŽP PřF UK v Praze]

Jersáková, J., Kindlmann, P. (2004). Zásady péče o orchidejová stanoviště, Kopp České Budějovice, $119 \mathrm{p}$.

Kovář, P. (1972). Krátký floristický príspěvek ke květeně České Třebové a okolí, Eastern Bohemia, Czech Republic. Zprávy ČBS, 7, p. 157-158.

Kovář, P. (1978). Př́spěvek k fytogeografii Českomoravského mezihoři (s doplňky k flóře za léta 1977-1981), Zprávy ČBS, 18, p. 49-60.

Kovár, P. (1981). The grassland communities of the southeastern basin of the Labe river. 1. Syntaxonomy. Folia Geobot. Phytotax., 16, p. 1-43.

Kovář, P. (2001). Geobotanika (Úvod do ekologické botaniky), skripta PřF UK v Praze, nakladatelství Karolinum, Praha.

Kováŕ, P. (2003). Železniční koridor versus poslední louky (střet za peníze EU), Živa, 51(6): 244-245.

Kovář P., Lepš, J. (1986). Ruderal communities of the railway station Česká Třebová (Eastern Bohemia, Czechoslovakia) - remarks on the application of classical and numerical methods of classification. Preslia, 58, 151-163.

Kovář, P., Jirásek, J. \& Grundová, H. (1996). Floristické kurzy ve Svitavách (1965) a Lanškrouně (1970): July 11-17, 1965, and in Lanškroun: July 2-10, 1970 (Eastern Bohemia, Czech Republic).Zprávy ČBS - Materiály 1996/2. 74 p.

Kubát, K. (2002). Klič ke květeně České republiky. Academia, Praha, 927 p.

Kubíková, J. (1971). Geobotanické praktikum, skripta PřF UK v Praze, nakladatelství Karolinum,. Praha.

Lepš, J., Šmilauer, P. (2000). Mnohorozměrná analýza ekologických dat. Scriptum. Biological Faculty, South-Bohemian University, České Budějovice, 102 p.

Málková, J. (2006). Botanické lokality Krskův di̊l a Betlém v Podorlicku. Východočeskou prírodou - Práce a studie, Pardubice, 13, p. 33-64.

Moravec, J. (1994). Fytocenologie, Academia, Praha, 403 p.

Moravec, J. (1995). Rostlinná společenstva České republiky a jejich ohrožení. Append. 1995, Severočeskou přírodou, prŕíloha 1995, 2nd Edition, [2. vydání,] Litoměřice.

Neuhäuslová, Z. (2001). Mapa potenciální přirozené vegetace České republiky, Academia, Praha, $341 \mathrm{p}$.

Neuhäusl, R., Neuhäuslová, Z. (1989). Polopřirozená travinná a vysokobylinná vegetace Železných hor, Studie ČSAV, 21-89, Academia, Praha, 200 p. 
Prach, K. (1994). Monitorování změn vegetace, metody a principy. Czech Institute for Nature Conservation, Praha, 69 p.

Prach, K. (1996). Úvod do vegetační ekologie, Jihočeská univerzita České Budějovice. Scriptum. Biological Faculty, South-Bohemian University. Ministry of the Environment of the Czech Republic, and PHARE, Praha, 95 p.

Prausová, R. (2002). Fytocenologický průzkum lučních ekosystémů v horní části povodi Kněžné na Rychnovsku (Východní Čechy). Východočeskou př́rodou - Práce a studie, Pardubice, 10, p. 107-203.

Quitt, E. (1971). Klimatické oblasti Československa. Studia Geographica 16, Inst. Geography, Cs. Acad. Sci., Brno.

Rybníček, K., Balátová-Tuláčková, E. \& Neuhäusl, R. (1984). Přehled rostlinných společenstev rašeliništ' a mokřadních luk Československa. Studie ČSAV, 8-84, Academia, Praha, 123 p.

Rychnovská, M., Balátová-Tuláčková, E., Úlehlová, B. \& Pelikán, J. (1985). Ekologie lučnich porostů. Academia, Praha, 292 p.

Sádlo, J. (2004). Zásady péče o nelesní biotopy v rámci soustavy Natura 2000. PLANETA $X I I, 3 / 2004$ - Part 2, Ministry of the Environment of the Czech Republic [druhá část. Ministerstvo životního prostředí, ČR] Praha.

Schrautzer, J. (1996). Restoration strategies for wet grasslands in Northern Germany. Ecological Engineering, 7: 255-278.

Slavík, B. (1997). Květena České republiky Volume 4. [in Czech]. Academia, Praha.

Suchara, I. (2007). Praktikum vybraných ekologických metod. Učební texty Univerzity Karlovy v Praze, Karolinum Praha.

Šmilauer, P. (1992). Cano Draw User's Guide v. 3.0, Microcomputer Power, Ithaca.

Tallowin, J.R.B., Smith, R.E.N. (2001). Restoration of a Cirsio-Molinietum fen meadow on an agriculturally improved pasture. Restoration ecology, 9(2), p. 167-178.

Ter Braak, C.J.F., Šmilauer, P. (1998). CANOCO Reference manual. Microcomputer Power. Ithaca.

Tichý, L. (2002). JUICE, Software for vegetation classification. J. Veg. Sci., 13, p. 451-453. Tichý, L., Holt, J. (2006). JUICE, Program for management, analysis and classification of ecological data, Program Manual. 97 p., Vegetation Science Group, Masaryk University, Brno. 
Photo 2: Detail of ,the last Dactylorhiza majalis“" at the edge of heavily disturbed wet meadow part of the grassland complex (May 2008; photo P.Kováŕ)

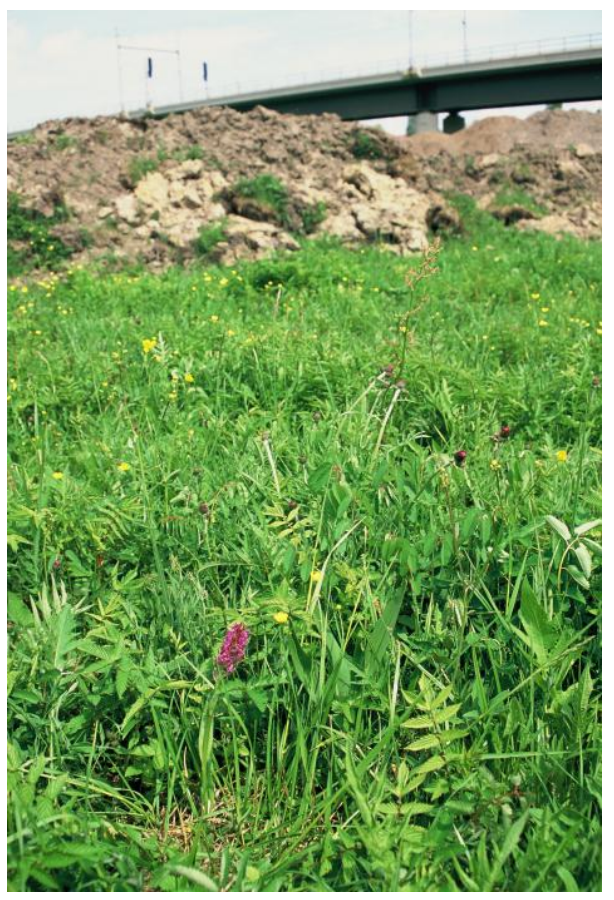

Photo 3: View on the area of new meadow disturbance two years after the finishing of the railway flyover construction where orchids found their last proper habitat (May 2008; photo P.Kováŕ)

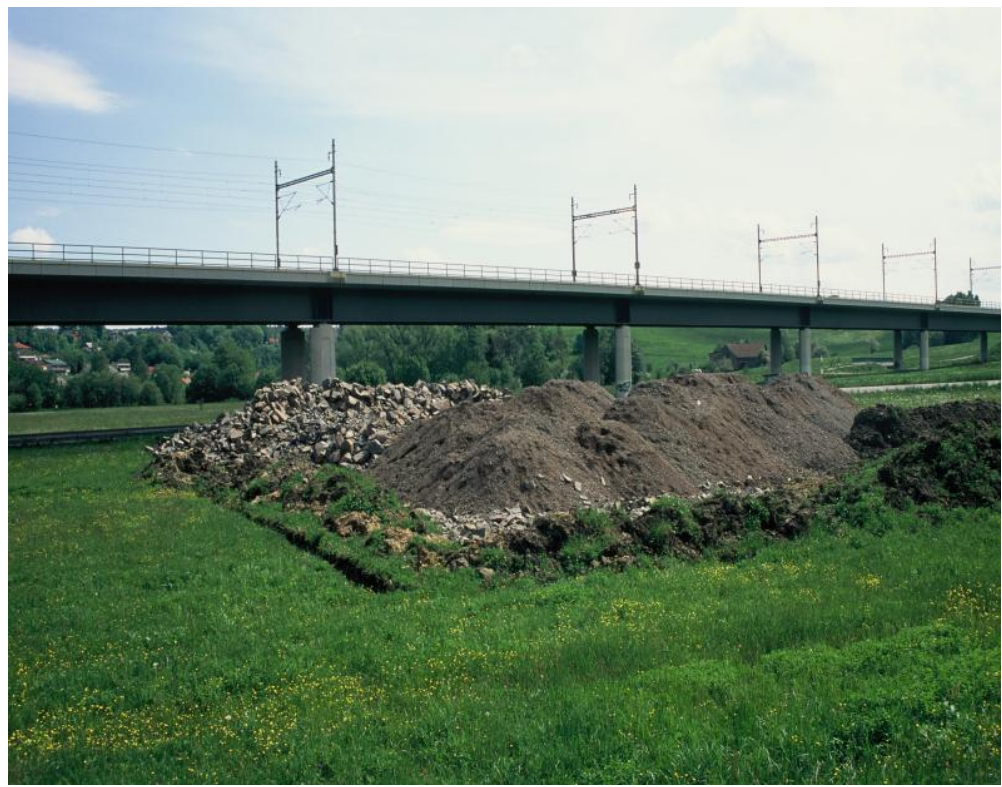

